УДК 343.1

\author{
Ю. П. Аленін
}

\title{
ШЛЯХИ ВДОСКОНАЛЕННЯ ПОЧАТКУ ДОСУДОВОГО РОЗСЛіДУВАННЯ
}

Більш ніж річна практика застосування нового КПК свідчить, що в розслідуванні кримінальних правопорушень з'явилися певні труднощі, які знайшли своє відображення в значному перевантаженні слідчих та прокурорів, здійснюючих безпосереднє процесуальне керівництво досудовим розслідуванням, що негативно впливає на якість самого розслідування в цілому, та розкритті та розслідуванні тяжких і особливо тяжких злочинів зокрема.

Взагалі треба відзначити, що у діяльності правоохоронних органів України одним $з$ найбільш складних була і $€$ проблема диференційованого підходу до вирішення заяв і повідомлень про злочини. Складність цього питання полягає в тому, що загальна кількість відповідних звернень з боку громадян та юридичних осіб щороку збільшується, а механізм їх перевірки так і досі належним чином не врегульований. Проте чітка правова регламентація процесуальної діяльності саме на першому етапі досудового провадження $€$ передумовою законності і обгрунтованості подальшого розслідування та судового розгляду справи, тобто $€$ однією з гарантій ефективного виконання завдань кримінального судочинства (ст. 2 КПК).

В концепції реформування кримінальної юстиції України, затвердженій Указом Президента України від 8 квітня 2008 р. № 311, наголошено на необхідності запровадження спрощеної процедури початку досудового розслідування, яким має вважатися момент отримання уповноваженими законом органами інформації про кримінальний проступок або злочин. Як наслідок, в КПК України з'явилася ст. 214, згідно з якою у кримінальному судочинстві України відмовилися від прийняття процесуального рішення про порушення кримінальної справи.

Відповідно до ч. 1-4 цієї статті, основні положення їх зводяться до такого.

(C) Аленін Ю. П., 2013 
Слідчий, прокурор невідкладно, але не пізніше 24 годин від моменту подання заяви, повідомлення про вчинене кримінальне правопорушення або самостійного виявлення ним з будь-якого джерела обставин, що можуть свідчити про вчинене кримінальне правопорушення, зобов'язаний внести відповідні відомості до Єдиного реєстру досудових розслідувань та розпочати розслідування, тобто розслідування починається 3 моменту внесення інформації до реєстру. До внесення такої інформації здійснення досудового розслідування не допускається, за винятком проведення у невідкладних випадках огляду місця події. Слідчий, прокурор, інша службова особа, уповноважена на прийняття заяв і повідомлень про кримінальні правопорушення, зобов'язані прийняти та зареєструвати таку заяву чи повідомлення. Відмова у прийнятті їх не допускається.

Аналізуючи зміст цих частин ст. 214 КПК, можна зробити декілька висновків як позитивного, так і негативного характеру.

Так, інформація про вчинене діяння, передбачене Законом України про кримінальну відповідальність, або підготовку до нього приймається від громадян, службових осіб, підприємств, організацій, установ в усній, письмовій чи в іншій формі. Завідомо неправдиві заяви, повідомлення про вчинення кримінального правопорушення повинні тягнути передбачену законом відповідальність (ст. 383 KK).

Слідчий, прокурор не вправі відмовити в прийнятті заяви, повідомлення чи іншої інформації про діяння, передбачене законом України про кримінальну відповідальність, у тому числі з посиланням на неповноту викладених у них відомостей, неналежність заяви чи повідомлення, закінчення строку давності притягнення до кримінальної відповідальності, віку, стан здоров'я особи та будь-які інші обставини.

Очевидно, що одночасно з прийняттям заяви, повідомлення чи іншої інформації про кримінальне правопорушення слідчим, прокурором повинні вживатися всі можливі заходи, щоб запобігти такому діянню або припинити його. За наявності відповідних підстав, що свідчать про реальну загрозу життю та здоров'ю особи, яка повідомила про діяння, передбачене законом України про кримінальну відповідальність, вживаються необхідні заходи забезпечення безпеки заявника, а також членів його сім'ї та близьких родичів, якщо шляхом погроз або інших протиправних дій щодо них робляться спроби вплинути на заявника. Але в ст. 214 ҚПК таке положення не передбачене і взагалі право на забезпечення безпеки заявника та інших осіб, які беруть участь у кримінальному судочинстві, в КПК подані досить стисло і лише в окремих нормах, а не в концентрованому вигляді, як це мало місце в Кодексі 1960 р. (див. ст. ст. 521-532), де докладно були виписані права осіб та регламентована процедура забезпечення безпеки суб'єктів кримінального провадження. Наведене свідчить про певний недолік нового КПК.

Джерелами інформації про вчинені або підготовлювані діяння, передбачені законом України про кримінальну відповідальність, яка надійшла до слідчого, прокурора, судді, тобто приводами, є: заяви та повідомлен- 
ня громадян; повідомлення уповноваженої особи, яка затримала особу, підозрювану у вчиненні злочину (ст. 208 КПК); повідомлення службових осіб державних органів, установ, підприємств та організацій; засобів масової інформації; з'яви із зізнанням; безпосереднє виявлення оперативним підрозділом, слідчим, прокурором, судом відомостей про ознаки діяння, передбаченого законом України про кримінальну відповідальність, при здійсненні своїх повноважень.

Автори заяв і повідомлень мають право надати документи та інші матеріали, які $є$ в них і підтверджують зроблені заяви чи повідомлення, за винятком випадків, коли конфіденційність чи таємність цих матеріалів гарантується законом.

Заяви громадян про вчинені кримінальні правопорушення або підготовку до них можуть бути усними або письмовими. У зв'язку з цим треба відзначити, що наявність спрощеного порядку ще не означає огульного, без розбору підходу до прийняття та реєстрації всіх без винятку заяв та повідомлень про кримінальні правопорушення (дійсні та надумані). Очевидно, що повинна існувати і певна, хоч і проста, але ефективна процедура прийняття й фіксації інформації, що надається, 3 метою запобігання безпідставному початку досудового розслідування. На жаль, цього ст. 214 КПК не передбачає, а тому, на наш погляд, слід дотримуватися таких правил, які не суперечать решті процесуальних норм. Зокрема, письмова заява повинна бути підписана особою, від якої вона подається. До внесення відомостей до Єдиного реєстру досудових розслідувань та початку досудового розслідування слід пересвідчитися в особі заявника. Якщо заявник не може пред'явити документи, повинні бути вжиті інші заходи для термінової перевірки відомостей про його особу. Вважаємо, що не підписана або підписана підробленим підписом чи написана від імені вигаданої особи заява, лист чи інше повідомлення про діяння, передбачене законом про кримінальну відповідальність, не може служити приводом до занесення в Єдиний реєстр та початку досудового розслідування. Вважаємо також за доцільне, щоб усна заява про кримінальне правопорушення заносилась до протоколу, який підписують заявник та службова особа органу досудового розслідування чи прокуратури, яка прийняла заяву. Протокол повинен містити відомості про заявника або особу, яка затримала підозрюваного на місці злочину, місце його проживання, а також про його особисті документи, які посвідчують його особу. До протоколу заносяться від першої особи повідомлення про обставини вчиненого чи підготовлюваного діяння, передбаченого законом України про кримінальну відповідальність.

При прийнятті усної заяви чи повідомлення про кримінальне правопорушення заявник у протоколі під розписку попереджається про кримінальну відповідальність за завідомо неправдиве повідомлення про вчинення злочину (ст. $383 \mathrm{KK}$ ). У разі надходження письмової заяви чи повідомлення про діяння, передбачене законом України про кримінальну відповідальність, бажано, щоб у заявника окремо відбиралася підписка 
про його попередження про кримінальну відповідальність за завідомо неправдиве повідомлення про злочин, яка долучається до матеріалів кримінального провадження. Якщо особа відмовилася підписати такий протокол чи дати таку підписку, в яких вона попереджена про кримінальну відповідальність за завідомо неправдиве повідомлення про злочин або підготовку до нього, така заява, на наш погляд, не повинна прийматися, розглядатися, не може бути підставою для внесення відомостей до Єдиного реєстру та початку досудового розслідування. 3 цих причин не підлягають розгляду та реєстрації анонімні заяви та повідомлення про злочин. Мета таких вимог до заяв та повідомлень про кримінальні правопорушення або підготовку до них полягає в тому, щоб запобігти появі доносів та зловживань з боку недобросовісних заявників.

У ст. 214 ҚПК залишається без відповіді питання, яким чином можна пересвідчитися в особі заявника, якщо повідомлення про кримінальне правопорушення зроблено ним по телефону. Очевидно, що тут підставою для внесення до Єдиного реєстру і початку досудового розслідування буде не інформація з телефонного дзвінка, а результати іiі негайної перевірки уповноваженими на те особами, оскільки пересвідчитися в особі заявника по телефону не завжди уявляється можливим.

Особливо ретельно треба відноситися до фіксації факту з'явлення особи із зізнанням, оскільки достовірно засвідчена така подія породжує в майбутньому важливі правові наслідки для заявника, мається на увазі, що в п. 1 ч. 1 ст. 66 KК явка $з$ повинною розглядається як обставина, що пом'якшує покарання.

Аналізуючи в цілому положення ст. 214 КПК, ми не повністю підтримуємо надто оптимістичну думку деяких авторів [1, с. 4; 2] про те, що запропонований КПК процесуальний порядок прийняття, реєстрації заяв та повідомлень про вчинене кримінальне правопорушення та початок досудового розслідування є надійною і ефективною гарантією забезпечення дотримання законності й обгрунтованості розгляду такої інформації на першому етапі стадії досудового розслідування.

Зокрема, слід зазначити, що ст. 214 ҚПК не $є$ еквівалентом стадії 3 перевірки заяв та повідомлень про злочини, яка раніше існувала як стадія порушення кримінальної справи. Незважаючи на певні недоліки в правозастосуванні, які пов'язані в більшій мірі не з процесуальною формою, а з позапроцесуальними чинниками, вказана стадія все ж таки дозволяла досить ефективно фільтрувати повідомлення і заяви про злочини і відділяти некримінальні події.

Варто також підкреслити, що запропонований КПК порядок початку досудового розслідування фактично скасовує так звану дослідчу перевірку за заявами та повідомленнями про вчинення кримінального правопорушення. Відтак усе процесуальне навантаження щодо перевірки таких заяв і повідомлень автоматично покладається на слідчого, а не на відповідні підрозділи, які здійснюють оперативно-розшукову діяльність. Отже, складається ситуація, за якої слідчі вимушені перевіряти найаб- 
сурдніші заяви під час досудового слідства, у той час, коли відповідного слідчого реагування вимагатиме розслідування тяжких та особливо тяжких злочинів. А це не сприяє підвищенню якості досудового розслідування і ефективності захисту прав громадян правоохоронними органами.

Слід звернути увагу і на те, що КПК не враховує особливості початку провадження щодо окремих категорій громадян, які користуються імунітетом (наприклад, народних депутатів України, суддів). Відповідно, слідчий, отримавши інформацію про вчинення кримінального правопорушення народним депутатом України та іншими особами, повинен розпочати розслідування.

Загалом, процесуальний порядок, запропонований ст. 214 КПК, не враховує загальні положення процесуальної діяльності та національні правові традиції. Будь-яка процесуальна галузь процесуального права повинна передбачати попередній, перевірочний, фільтраційний етап перед основним провадженням. Специфікою кримінального судочинства $€$ й те, що в ньому декілька основних проваджень: досудове розслідування, судовий розгляд, перегляд судових рішень повинні мати відповідний фільтраційний механізм.

Запропонований порядок розпочинання досудового розслідування також не передбачає прийняття відповідного процесуального рішення у формі постанови слідчого або прокурора, що не узгоджується з ч. 3 ст. 110 КПК, згідно з якою рішення слідчого приймаються саме у формі мотивованої постанови. Окрім того, відсутність формального початку кримінального провадження у формі постанови також робить неможливим оскарження факту його порушення. Зазначений механізм розпочинання досудового розслідування не передбачає і здійснення за ним судового контролю, що не узгоджується з Рішенням Конституційного Суду України у справі про розгляд судом окремих постанов слідчого і прокурора від 30 січня 2003 р. У вказаному рішенні Конституційний Суд України зазначив: унеможливлення розгляду судом скарги на постанову про порушення кримінальної справи шодо певної особи на стадії досудового слідства, відкладення ii перевірки судом на стадію попереднього розгляду кримінальної справи або на стадію розгляду іiі по суті, відстрочка судового контролю обмежують конституційне право людини на судовий захист, який $€$ гарантією всіх прав і свобод людини і громадянина. Правосуддя за своєю суттю визнається таким лише за умови, шо воно відповідає вимогам справедливості і забезпечує ефективне поновлення в правах. Загальною декларацією прав людини 1948 року передбачено, що кожна людина має право на ефективне поновлення в правах компетентними національними судами у випадках порушення іï основних прав, наданих їй конституцією або законом (ст. 8). Право на ефективний засіб захисту закріплено також у Міжнародному пакті про громадянські та політичні права (ст. 2) і в Конвенції про захист прав людини та основних свобод (ст. 13). Право на судовий захист прав людини є одним з конституційних прав. А тому положення ч. 6 ст. 234, ч. 3 ст. 236 КПК України, які 
унеможливлюють розгляд судом на стадії судового слідства скарг на постанови слідчого та прокурора про порушення кримінальної справи щодо певної особи, обмежуючи право людини на судовий захист, закріплене ч. 3 ст. 8, ч. 1, 2 ст. 35 Конституції України, порушують вимоги ч. 3 ст. 21, ч. 2 ст. 22, ч. 1 ст. 64 Конституції України, тобто $є$ неконституційними. Скарги до суду на постанови слідчого та прокурора про порушення кримінальної справи щодо певної особи повинні розглядатися судом за чинним законодавством у порядку кримінального судочинства. При цьому суд, розглядаючи такі скарги на стадії досудового слідства, перевіряє наявність приводів і підстав для винесення зазначених постанов і не повинен розглядати та вирішувати заздалегідь ті питання, які повинен вирішувати суд при розгляді кримінальної справи по суті, оскільки це буде порушенням конституційних засад правосуддя.

Таким чином, унеможливлення (внаслідок відсутності постанови) розгляду судом скарги на відкриття кримінального провадження на стадії досудового розслідування, відкладення ii перевірки судом на стадію попереднього (підготовчого) провадження або на стадію розгляду іiі по суті, відстрочка судового контролю обмежують конституційне право людини на судовий захист, який є гарантією всіх прав і свобод людини і громадянина. Про те, що право на оскарження відкриття кримінального провадження є суттєвою гарантією захисту прав і законних інтересів громадянина та юридичних осіб, свідчить і судова практика, адже наявність положення, передбаченого п. 1 ч. 1 ст. 303 КПК, згідно з яким на досудовому провадженні можуть бути оскаржені до слідчого судді бездіяльність слідчого, прокурора, яка полягає у невнесенні відомостей про кримінальне правопорушення до Єдиного реєстру досудових розслідувань після отримання заяви або повідомлення про кримінальне правопорушення ні в якій мірі не замінюють того, що існував раніше, повноцінного інституту оскарження дій (бездіяльності) слідчого, прокурора на стадії порушення кримінальної справи.

Підкреслимо також, що ст. 214 ҚПК ініціювання кримінально-процесуальної діяльності покладається на особу, яка звертається із заявою чи повідомленням. Вбачається, що такий порядок $€$ надто спрощеним i може призвести до зловживань, з боку як органів досудового розслідування, так і осіб, які звертаються із заявами чи повідомленнями. Досудовому розслідуванню має передувати перевірочна діяльність компетентних органів та осіб, результати якої повинні бути формалізовані у відповідному процесуальному документі: постановах про початок або про відмову в початку досудового розслідування, який в чинному законодавстві має лінгвістично некоректну назву, проте по суті і функціонально означає порушення кримінального провадження. А відтак вважаємо, що на етапі ініціювання досудового розслідування необхідно запровадити своєрідний процесуальний фільтр, завдяки якому кримінальне провадження буде розпочинатися за діяннями, які дійсно мають ознаки злочину чи кримінального проступку. 
Отже можна зробити остаточний висновок, який базується як на практиці застосування нового КПК, так і розробках багатьох вчених [38], що в процесуальному регулюванні початку досудового розслідування мають суттєві недоліки, прогалини, а тому до ҚПК слід внести відповідні зміни та доповнення і статтю 214 викласти в такій редакції.

1. Приводами (джерелами) до початку досудового розслідування $€$ : 1) заяви або повідомлення підприємств, установ, організацій, посадових осіб, представників влади, громадськості або окремих громадян; 2) повідомлення представників влади, громадськості або окремих громадян, які затримали особу за підозрою у вчиненні кримінального правопорушення без ухвали слідчого судді, суду про дозвіл на затримання; 3) явка з повинною; 4) повідомлення про вчинені або про підготовлювані кримінальні правопорушення, які отримані з інших джерел.

2. Підставою для початку кримінального провадження $€$ наявність достатніх даних, що вказують на ознаки діяння, передбаченого кримінальним законодавством України.

3. Заяви або повідомлення про кримінальне правопорушення можуть бути усними або письмовими. Усні заяви заносяться до протоколу, який підписують заявник та посадова особа, що прийняла заяву. Заявник попереджається про кримінальну відповідальність за завідомо неправдиве повідомлення про вчинення злочину відповідно до ст. 383 КК України.

Повідомлення службових осіб, органів, установ, підприємств та організацій про вчинення кримінального правопорушення викладається в письмовій формі. До повідомлення можуть бути додані документи і предмети, які підтверджують обставини вчинення діяння, передбаченого законом України про кримінальну відповідальність.

Явка з повинною - добровільне, особисте і безпосереднє письмове чи усне повідомлення заявником слідчому, прокурору, судді або суду про кримінальне правопорушення до початку досудового розслідування. Якщо кримінальне провадження вже розпочато, таке повідомлення заявником має бути зроблене до його повідомлення про підозру.

Усна заява заноситься до протоколу, в якому зазначаються відомості про особу заявника і зміст його заяви від першої особи. Протокол підписують заявник і посадова особа, яка склала протокол.

Якщо усна заява про явку з повинною зроблена в судовому засіданні, то відомості про особу заявника і зміст його заяви заносяться до журналу судового засідання і підписуються заявником. Слідчий суддя або головуючий протягом трьох днів надсилає витяг з журналу судового засідання відповідному прокурору.

Письмова заява про явку з повинною має бути підписана заявником і посадовою особою, яка прийняла заяву, із зазначенням на заяві дати iï прийняття.

Особа, яка звернулася з заявою про явку з повинною користується правами заявника, передбаченими ч. 2 ст. 60 КПК України.

4. Слідчий, прокурор невідкладно, але не пізніше 24 годин після 
подання заяви, повідомлення про вчинене кримінальне правопорушення або після самостійного виявлення ним з будь-якого джерела обставин, що можуть свідчити про вчинення кримінального правопорушення, зобов'язаний внести відповідні відомості до Єдиного реєстру досудових розслідувань.

Одночасно слідчий зобов'язаний вжити всіх можливих заходів, щоб запобігти кримінальному правопорушенню або припинити його. За наявності відповідних підстав, що свідчать про реальну загрозу життю та здоров’ю особи, яка повідомила про кримінальне правопорушення, слід вжити необхідних заходів для забезпечення безпеки заявника, а також членів його сім’ї та близьких родичів, якщо шляхом погроз або інших протиправних дій щодо них робляться спроби вплинути на заявника.

5. Коли необхідно перевірити заяву або повідомлення про кримінальне правопорушення, така перевірка здійснюється слідчим, прокурором в строк не більше десяти днів з моменту внесення відомостей до Єдиного реєстру досудових розслідувань. Протягом проведення такої перевірки забороняється вчинення будь-яких слідчих дій, передбачених цим Кодексом, за винятком огляду місця події у невідкладних випадках. Перевірка може проводитися шляхом відібрання пояснень від окремих громадян чи посадових осіб, витребування необхідних документів чи їх копій, одержання висновків спеціалістів у відповідних галузях знань або проведення ревізій, матеріалів перевірки.

6. За результатами проведення перевірки відомостей про кримінальне правопорушення слідчий, прокурор приймає постанову про початок досудового розслідування або постанову про відмову в початку такого розслідування.

Постанови, прийняті за результатами проведення перевірки відомостей про кримінальне правопорушення, можуть бути оскаржені до слідчого судді.

7. Слідчий, прокурор в постанові про початок досудового розслідування вказує приводи і підстави, статтю кримінального закону, за ознаками якої розпочинається кримінальне провадження.

Якщо на момент прийняття рішення про початок досудового розслідування встановлено особу, яка вчинила кримінальне правопорушення, кримінальне провадження повинно бути почато щодо цієї особи.

Після початку досудового розслідування прокурор направляє матеріали кримінального провадження відповідному слідчому з дотриманням правил підслідності та доручає ведення досудового розслідування.

Якщо слідчий самостійно прийняв рішення про початок досудового розслідування, то він в письмовій формі повідомляє про це прокурора i після прийняття на себе кримінального провадження починає досудове розслідування.

У разі початку кримінального провадження прокурор, слідчий зобов'язаний негайно вручити копію відповідної постанови особі, щодо якої розпочато досудове розслідування, та потерпілому. При неможливості 
негайного вручення копія постанови вручається не пізніше трьох діб 3 моменту їі винесення. У разі неможливості вручення зазначеним особам копії постанови про початок досудового розслідування у вказаний вище строк через їх хворобу, неможливість встановлення місця перебування чи 3 інших поважних причин, копія постанови вручається протягом трьох діб з моменту явки, приводу чи встановлення місця перебування цих осіб.

Якщо особа відмовляється одержати копію постанови про початок досудового розслідування, прокурор, слідчий складають відповідний протокол. Представнику потерпілого, захиснику чи законному представнику підозрюваного копія постанови про початок досудового розслідування вручається або надсилається на їх письмову вимогу протягом трьох діб з моменту надходження такої вимоги.

8. При відсутності підстав до початку досудового розслідування прокурор, слідчий своєю постановою відмовляє у початку досудового розслідування, про що повідомляють зацікавлених осіб і підприємства, установи, організації.

Відомості про відмову у початку досудового розслідування також вносяться до Єдиного реєстру досудових розслідувань.

Якщо в результаті перевірки заяви чи повідомлення, що надійшли, не встановлено підстав для початку досудового розслідування, але матеріали перевірки містять дані про наявність у діянні особи адміністративного чи дисциплінарного проступку, прокурор, слідчий вправі відмовити в початку досудового розслідування, надіслати заяву або повідомлення до компетентного органу для порушення провадження в справі про адміністративний або дисциплінарний проступок.

\section{Л і т е р а т у р а}

1. Фаринник В. І̇. Початок досудового розслідування за Кримінальним процесуальним кодексом України / B. I. Фаринник // Юридичний вісник України. - 2012. - № 24, 16-22 черв. - C. 4.

2. Татаров О. Ю. Початок досудового розслідування за Кримінальним процесуальним кодексом України [Електронний ресурс] / О. Ю. Татаров. - Режим доступу: http:/ /www.dduvs.dp.ua/assets/files/news3/KPK/material.doc.

3. Волобуєв А. Ф. Проблемні питання початку досудового розслідування / A. Ф. Волобуєв // Актуальні проблеми кримінального права, процесу та криміналістики : матеріали V Міжнар. наук.-практ. конф., присвяч. 20-річчю Нац. акад. правових наук України (м. Одеса, 1 листоп. 2013 р.). - О., 2013. - С. 237-240.

4. Татаров О. Ю. Застосування деяких положень нового ҚПК України потребує унормування / О. Ю. Татаров // Митна справа. - 2013. - № 4, ч. 2, кн. 1. - С. 182-187.

5. Якубова А. З. Окремі аспекти початку досудового розслідування за новим кримінальним процесуальним законодавством України / А. 3. Якубова // Науковий вісник Ужгородського національного університету. - 2012. - С. 139-141.

6. Берназ В. Регламентація початку досудового розслідування як основа кримінальнопроцесуального провадження / В.Берназ, Н. Неледва // Вісник прокуратури. 2013. - № 1. - C. 62-67. 
7. Чурікова І̇. В. Початок досудового розслідування у кримінальному процесі України / I. В. Чурікова // Юридичний часопис Національної академії внутрішніх справ. 2013. - № 2. - C. 226-231.

8. Юрченко Л. В. Особливості початку досудового розслідування за новим кримінальним процесуальним законодавством України / Л. В. Юрченко // Ученые записки Таврического национального университета им. В. И. Вернадского. Серия «Юридические нации». - 2013. - Т. 26, № 1. - С. 338-343.

\section{A н о т а ц і я}

Аленін Ю. П. Шляхи вдосконалення початку досудового розслідування. Стаття.

Стаття присвячена дослідженню проблем початкового етапу стадії досудового розслідування - нового процесуального інституту, який введений замість процедури порушення кримінальної справи, що існувала. Об'єктом дослідження $є$ позитивні та негативні аспекти появи пропонованого новим КПК України процесуального порядку початку досудових розслідувань кримінальних правопорушень.

Ключові слова: стадія досудового розслідування, початок розслідування, заяви i повідомлення про правопорушення, Єдиний реєстр досудових розслідувань.

\section{А н н о т а ци я}

Аленин Ю. П. Пути усовершенствования начала досудебного расследования. Статья.

Статья посвящена исследованию проблем начального этапа стадии досудебного расследования - нового процессуального института, который введен вместо существовавшей процедуры возбуждения уголовного дела. Объектом исследования являются позитивные и негативные аспекты появления предлагаемого новым УПК Украины процессуального порядка начала досудебных расследований уголовных правонарушений.

Ключевые слова: стадия досудебного расследования, начало расследования, заявления и сообщения о правонарушениях, Единый реестр досудебных расследований.

\section{S u m m a r y}

Alenin J.P. The ways of improvement of the initial stage of pre-trial investigation phase. - Article.

The article is devoted to research the problems of the initial stage of pre-trial investigation phase, a new proceeding Institute, that was introduced instead of existed criminal proceedings. The object of research is predicted positive and negative aspects of appearance offered by a new Criminal Procedure Code order of initial stage of pre-trial investigation phase of criminal offenses.

Keywords: pre-trial stage, initial stage of investigation, indictment, the Single register of pre-trial investigations. 